\title{
Fishing pattern and environmentally friendly analysis on mud crab (Scylla spp.) fishery in Mojo mangrove ecosystem, Pemalang Regency, Central Java, Indonesia
}

\author{
Trisnani Dwi Hapsari ${ }^{1 *}$, Azis Nur Bambang ${ }^{1}$, Abdul Ghofar ${ }^{2}$, and Aristi Dian Purnama \\ Fitri $^{1}$ \\ ${ }^{1}$ Department of Fishing Capture, Faculty of Fisheries and Marine Science, Diponegoro University. Jl. \\ Prof. Soedarto, SH, Tembalang, Semarang 50275, Central Java, Indonesia \\ ${ }^{2}$ Department of Aquatic Resource Management, Faculty of Fisheries and Marine Science, Diponegoro \\ University. Jl. Prof. Soedarto, SH, Tembalang, Semarang 50275, Central Java, Indonesia.
}

\begin{abstract}
The high market demand of mud crabs has led to increase the capture so that their availability in the wild is threatened. The purpose of this study was to determine the fishing pattern of mud crabs and analyze the environmentally friendly of mud crab catching units in Mojo mangrove ecosystem. Data analysis used descriptive analysis to analyze the fishing pattern and analysis of the level of environmentally friendly based on nine FAO criteria. From the research it is known that the peak season of mud crabs fishing occurs during the west monsoon season and the usual season during the east monsoon season, while the famine season at the end of the east monsoon season. Observation results indicate that the majority of mud crabs caught are not in accordance with regulations ( $\mathrm{size}<12 \mathrm{~cm}$ ) with $70 \%$ of the total catch of mud crabs for soft shell crab farming needs. Based on environmental analysis of fishing gear, it is known that crab traps, trammel net, crabbing with a line and scoop net are environmentally friendly fishing gear with a score of $32.37,26.81$ and 32.40 . However, there are criteria that do not meet environmentally friendly scores, namely the capture of mud crabs of a prohibited size and many non-target species caught with trammel net fishing gear.
\end{abstract}

\section{Introduction}

The Mojo mangrove ecosystem is one of the potential sources of mangrove crabs or mud crabs that have high economic value. The activity of catching mud crabs in Pemalang Regency has increased in intensity since the business of mud crab fattening and soft-shell crab cultivation activities developed in Mojo Village, Ulujami District since 2005. The high market demand both locally and globally has led to an increase in the capture of mud crabs so that their availability in the wild is threatened. Based on the Minister of Fisheries and Maritime Affairs Regulation No. 12 Year 2020 (revision of the Minister of Maritime Affairs

* Corresponding author: trisnanihapsari@live.undip.ac.id 
and Fisheries Regulation No.1 Year 2015 and Regulation No. 56 Year 2016), mud crab fishing can be done with the provisions of carapace widths above $12 \mathrm{~cm}$ or weights above 150 grams per individual. But in reality many fishermen do not comply with these regulations, causing overfishing of mud crab resources.

The purpose of this study was to determine the fishing pattern of mud crabs and analyze the environmentally friendly of mud crab catching units in Mojo Mangrove Ecosystem. Research on the identification of fishing gear based on the criteria of the Code of Conduct for Responsible Fisheries is important to be done as a foundation for relevant stakeholders, in making a policy of management of mud crab resources in the mojo mangrove ecosystem without ignoring the ecology (environment) for the realization of sustainable fisheries.

\section{Methodology}

The method used in this research is Mixed Method, which is by combining qualitative and quantitative research types [1, 2, 3, 4]. Data collection methods included interviews with questionnaire aids and direct observation in Mojo Village, Ulujami District, Pemalang Regency. Sampling method used was snowball sampling. The number of mud crab fishermen who become respondents in this study is 63 people consist of 22 crab traps fishermen, 26 trammel net fishermen and 24 crabbing with a line and scoop net fishermen.

Model analysis of the assessment of the environmental friendliness of a fishing gear, in principle emphasized on things that directly affect the environment in which the fishing gear is operated. In determining the level of friendliness of mangrove crab fishing equipment in supporting responsible fisheries, the criteria for environmentally friendly fisheries are determined as stated in the Code of Conduct for Responsible Fisheries, FAO [5, 6, 7, 8]. These criteria are then given a score. the scoring of each fishing gear for each criterion is 1 to 4 . To facilitate the assessment, each main criterion is broken down into 4 sub criteria.

Table 1. Scoring criteria for environmentally friendly fishing gear based on the CCRF

\begin{tabular}{|c|c|c|c|}
\hline No & Criteria & Description & Score \\
\hline \multirow[t]{5}{*}{1} & $\begin{array}{l}\text { Fishing gear } \\
\text { selectivity }\end{array}$ & $\begin{array}{l}\text { These criteria are set based on the selectivity of the size and } \\
\text { selectivity of type. These Sub-criteria consist of: }\end{array}$ & \\
\hline & & $\begin{array}{l}\text { The fishing gear catch more than three species of far } \\
\text { different sizes }\end{array}$ & 1 \\
\hline & & . The fishing gear catch 1-3 species of far different sizes & 2 \\
\hline & & $\begin{array}{l}\text { The fishing gear catch less than three species with } \\
\text { approximately the same size }\end{array}$ & 3 \\
\hline & & $\begin{array}{l}\text { The fishing gear catch only one species with approximately } \\
\text { the same size }\end{array}$ & 4 \\
\hline \multirow[t]{5}{*}{2} & $\begin{array}{l}\text { Impact on } \\
\text { habitat }\end{array}$ & $\begin{array}{l}\text { These criteria are set based on the extent and level of damage } \\
\text { posed. These Sub-criteria consist of: }\end{array}$ & \\
\hline & & Causing habitat damage to large areas & 1 \\
\hline & & - Causing habitat damage in narrow areas & 2 \\
\hline & & - Causing some habitat damage in narrow areas & 3 \\
\hline & & - Safe for habitat (not damaging habitat) & 4 \\
\hline \multirow[t]{2}{*}{3} & $\begin{array}{l}\text { Quality of } \\
\text { catch }\end{array}$ & $\begin{array}{l}\text { These criteria are determined based on the conditions of the } \\
\text { morphological (form) of cathes. These sub-criteria consist of: }\end{array}$ & \\
\hline & & . Dead and rotten fish & 1 \\
\hline
\end{tabular}




\begin{tabular}{|c|c|c|c|}
\hline & & Dead fish, fresh and physically disabled & 2 \\
\hline & & Fresh dead fish & 3 \\
\hline & & Live Fish & 4 \\
\hline \multirow[t]{5}{*}{4} & $\begin{array}{l}\text { Safety of the } \\
\text { fishing gear } \\
\text { operation }\end{array}$ & $\begin{array}{l}\text { These criteria are applied based on hazard and impact levels } \\
\text { that fishermen may experience. These sub-criteria consist of: }\end{array}$ & \\
\hline & & $\begin{array}{l}\text { Fishing gear and how to use them can result in death in } \\
\text { fishermen }\end{array}$ & 1 \\
\hline & & $\begin{array}{l}\text { The fishing gear and its use can result in permanent } \\
\text { disability of fishermen }\end{array}$ & 2 \\
\hline & & $\begin{array}{l}\text { The fishing gear and its use can result in health problems } \\
\text { temporary }\end{array}$ & 3 \\
\hline & & Safe capture equipment for fishermen & 4 \\
\hline \multirow[t]{5}{*}{5} & $\begin{array}{l}\text { Product safety } \\
\text { for consumers }\end{array}$ & $\begin{array}{l}\text { These criteria are established based on hazard levels for } \\
\text { consumers. These Sub-criteria consist of: }\end{array}$ & \\
\hline & & . Can cause death & 1 \\
\hline & & - Can cause consumer health problems & 2 \\
\hline & & A very small opportunity for consumer health disorders & 3 \\
\hline & & Safe for consumers & 4 \\
\hline \multirow[t]{5}{*}{6} & $\begin{array}{l}\text { Non-target } \\
\text { species }\end{array}$ & $\begin{array}{l}\text { This criteria is determined by the number of non-target } \\
\text { species and level of utilization. These sub-criteria consist of: }\end{array}$ & \\
\hline & & $\begin{array}{l}\text { By-catch results are made up of several species that are not } \\
\text { sold on the market }\end{array}$ & 1 \\
\hline & & $\begin{array}{l}\text { By-catch consists of several species and there are sold in the } \\
\text { market }\end{array}$ & 2 \\
\hline & & $\begin{array}{l}\text { By-catch less than three species and can be sold in the } \\
\text { market }\end{array}$ & 3 \\
\hline & & $\begin{array}{l}\text { By-catch less than three species and the price is high in the } \\
\text { market }\end{array}$ & 4 \\
\hline \multirow[t]{5}{*}{7} & $\begin{array}{l}\text { Impact on } \\
\text { biodiversity }\end{array}$ & $\begin{array}{l}\text { These criteria are set based on hazard and impact levels of } \\
\text { biodiversity. These Sub-criteria consist of: }\end{array}$ & \\
\hline & & $\begin{array}{l}\text { The fishing gear and its operation cause the death of biota } \\
\text { and damage the habitats }\end{array}$ & 1 \\
\hline & & $\begin{array}{l}\text { The fishing gear and its operation cause the death of several } \\
\text { species and destroys the habitat }\end{array}$ & 2 \\
\hline & & $\begin{array}{l}\text { The fishing gear and its operation cause the death of several } \\
\text { species but does not damage the habitat }\end{array}$ & 3 \\
\hline & & Safe for biodiversity & 4 \\
\hline \multirow[t]{5}{*}{8} & $\begin{array}{l}\text { Impact on } \\
\text { protected } \\
\text { species }\end{array}$ & $\begin{array}{l}\text { These criteria are based on the hazard level of the fishing } \\
\text { gear to the protected species. These sub-criteria consist of: }\end{array}$ & \\
\hline & & - Protected fish are often caught by the fishing gear & 1 \\
\hline & & - Protected fish several times caught by the fishing gear & 2 \\
\hline & & Protected fish ever caught by the fishing gear & 3 \\
\hline & & - Protected fish never caught & 4 \\
\hline
\end{tabular}




\begin{tabular}{|c|l|l|c|} 
& & $\begin{array}{l}\text { A fishing gear is socially accepted by the community when: } \\
\text { (1) the cost of investment is cheap, (2) economically } \\
\text { profitable, (3) not contrary to local culture, (4) does not } \\
\text { conflict with the existing regulations. These sub-criteria } \\
\text { consist of: }\end{array}$ & \\
\hline 9 & $\begin{array}{l}\text { Social } \\
\text { acceptance }\end{array}$ & The fishing gear meets one of the four above statements & 1 \\
\hline & & $\begin{array}{l}\cdot \text { The fishing gear meets two of the four above statements } \\
\text { statements }\end{array}$ & 2 \\
\hline & & $\cdot$ The fishing gear meets all the above statements & 3 \\
\hline
\end{tabular}

After all the scores are obtained from the interview, a reference point is made by dividing the total score from the respondent by the number of respondents. Reference points are made to determine the final scoring results of each environmentally friendly fishing gear criteria with the following formula :

$$
X=\frac{\Sigma X n}{N}
$$

$\mathrm{X}=$ environmentally friendly score

$\Sigma \mathrm{Xn}=$ score total

$\mathrm{N}$ = number of respondents

After the score or the value has been obtained, then made reference points that can be a reference point in determining ranking. Here the maximum score is 36 points, while the category of environmentally friendly fishing gear will be divided into 4 categories with a range of values as follows: $1-9$ is very unenvironmentally friendly, 10-18 is unenvironmentally friendly, 19-27 is environmentally friendly, 28-36 is very environmentally friendly.

\section{Results and discussion}

\subsection{Fishing pattern}

\subsubsection{Mud crab fishing gear}

Crab fishery in Mojo Village mangrove ecosystem, commonly done by artisanal fishermen and crab collectors. Catching mud crabs is done anytime, both day and night, depending on the type of fishing gear used. Fishing gear used, i.e. Crab Traps, Trammel Net and Crabbing with a Line and Scoop Net. Crab Traps fishing gear can be done at any time because it is passive. While crabbing with a Line and Scoop Net (crab fishing line with bait and handpicking use iron rod/wooden stick with scoop net) operate during the day, but if it will be used at night is equipped with lighting (lights or torches). The number of fishing gear used to catch mud crabs and the fishing ground can be seen on Table 2. 
Table 2. Mud crab fishing gear and fishing ground

\begin{tabular}{|c|c|c|}
\hline $\begin{array}{c}\text { Type of } \\
\text { Fishing Gear }\end{array}$ & Total & Fishing Ground \\
\hline $\begin{array}{c}\text { Crab traps } \\
\text { (Folding trap, } \\
\text { Dome trap) }\end{array}$ & $30^{*}$ & around in front of estuary/lagoon \\
\hline Trammel net & $165^{*}$ & \multirow{2}{*}{$\begin{array}{c}\text { west of the river estuary/lagoon (west } \\
\text { monsoon season), east of the river } \\
\text { estuary (east monsoon season) }\end{array}$} \\
\hline $\begin{array}{c}\text { Crab fishing } \\
\text { line with bait }\end{array}$ & $20^{*}$ & \\
\hline $\begin{array}{c}\text { Handpicking } \\
\text { use iron } \\
\text { rod/wooden } \\
\text { stick with } \\
\text { scoop net }\end{array}$ & $\begin{array}{c}\text { part time crab collectors }= \\
70-140^{* *} \text { (estimation, } \\
\text { unknown exact number) }\end{array}$ & \multicolumn{1}{|c|}{ edge of pond, riverside, mangrove, } \\
\cline { 2 - 3 }
\end{tabular}

Source : $\quad{ }^{*}$ Marine and Fishery Office of Pemalang Regency (2019)

${ }^{* *}$ Data from Local Depot Owner

\subsubsection{Crab Trabs (Local name : Bubu/Wadong) Fishing Gear}

Crab Trabs are used in mud crab fishing in the Coastal Waters of Mojo Village, there are 2 forms, namely Folding Trap and Dome Trap. Catching mud crabs with Crab Traps using dead bait in the form of small demersal fish, such as mullet fish (Mugil chepalus), mangrove red snapper (Lutjanus argentimaculatus), pony fish(Leiognathidae) and goldband goatfish (Upeneus moluccensis). In one fishing fleet there are 2-3 sets of Crab Traps fishing gear. A set of fishing gear series consists of 80-90 units of Crab Traps, so that in one boat consists of 160-270 units of Crab Traps.

The use of fishing gear is done by placing it at the bottom of the water. Before the fishing gear installation process, bait installation is carried out, one Crab Traps unit is filled with 1 bait, the bait is placed in the middle of the fishing gear, the time needed to finish installing the entire bait is about 1 hour. After all the Crab Traps have been fitted with bait, the fishermen head for the fishing ground. Most fishermen check and move the location of the Crab Traps 2 times a day, at dawn around 03.00 WIB (hauling) and in the afternoon around 16.00 WIB (setting). The average catch of mud crabs (Scylla spp.) per day is 10-58 mud crabs (with a number of crab traps around 160-270 units), with an average weight of 120-370 grams per individual.

\subsubsection{Trammel net fishing gear}

Trammel net fishing gear which is used with a simpler construction and by local fishermen is called "crab net", the length of one unit of fishing gear is around $400 \mathrm{~m}$. The outer mesh is 3.5 inches and the inside is 1.5 inches. The principle of catching by trapping or wrapping the body of a crab by utilizing the tidal process of sea water. The operation is carried out from evening until dawn. While the principle of operation is the same as the gill net. This fishing gear is operated at night. During the season of many mud crabs, the operation of the trammel net is carried out in a wide shallow water (lagoon) expanse of water in the form of mud with 
a water depth of about 0.5 - 1 meter, depending on tides. Fishing ground is a former pond that was damaged due to coastal abrasion and surrounding mangrove forest.

Trammel net fishermen aside from Mojo Village, there are those who come from neighboring villages, from Limbangan Village and Pesantren Village. Catches with trammel net fishing gear include vanamei shrimp (Lithopenaeus vannamei), white shrimp (Penaeus merguiensis), blue swimming crab (Portunus pelagicus), milk fish (Chanos chanos), mullet fish (Mugill dossumieri), shuttles hoppfish (Periophthalmus modestus) [9]. Trammel net catches an average of 1-4 crabs with an average weight of 50-105 grams per individual.

\subsubsection{Crabbing with a Line and Scoop Net}

Crabbing with a Line and Scoop Net is mostly done by permanent crab collectors or fishermen who switch to catch mud crabs during the west monsoon season (usually January to May). The fishing methods used consists of 2 types, namely mud crab fishing line with bait and handpicking using iron rod / wooden stick with scoop net. Fishing activities are carried out in the morning or at night, but the majority are carried out at night because mud crabs are nocturnal animals that are active at night $[10,11]$, when during the day the mud crab hide by burrowing / entering into mud holes [12, 13]. Spot Crabbing with a Line and Scoop Net are usually in ponds or estuaries near mangrove trees, when low tide mud crabs are found in shrimp ponds and in lagoons.

Crab fishing line with bait fishing gear requires equipment that includes lines, hooks, rods, and scoop net to take crabs. The activity of catching mud crab by fishing line by installing a fixed line of fishing on the edges of the pond with a total of 20-30 fishing lines. The mud crab caught does not get caught on the hook, but only biting the bait so it is quickly taken with a scoop net.

Then another method for crabbing is by handpicking use the iron rods/wooden sticks for digging holes until mud crabs out of their holes, or uses hooks to drag them out. After coming out, the fishermen catch crabs using scoop net. The torch (flashlight) is used by fishermen as a lighting aid at night. Based on interviews the average catch of mud crabs (Scylla spp.) by way of Crabbing with a Line and Scoop Net varies in number depending on the season, the number of hooks and expertise of crab seekers / fishermen doing crabbing.

\subsubsection{Fishing season and catches of mud crabs}

Mud crabs fishing is carried out throughout the year, the harvest season occurs when it enters the rainy season. The peak season occurs after 2-3 months after the rainy season occurs. The peak season occurs during the west monsoon season (February - May), while the usual season occurs in the east monsoon season (June-August), the famine season in August - January and during the full moon because there is no tidal period.

The activity of fishing local fishermen is one day trip so that the fishing is carried out every day, except on Friday Kliwon (sacred time according to Javanese belief) and religious holidays. Many mud crabs are caught at night. During the day, they immerse themselves, and appear at sunset to look for prey $[14,15]$. Scylla spp. spends most of the night walking on the surface of the substrate or in a stationary position $[16,17]$. 


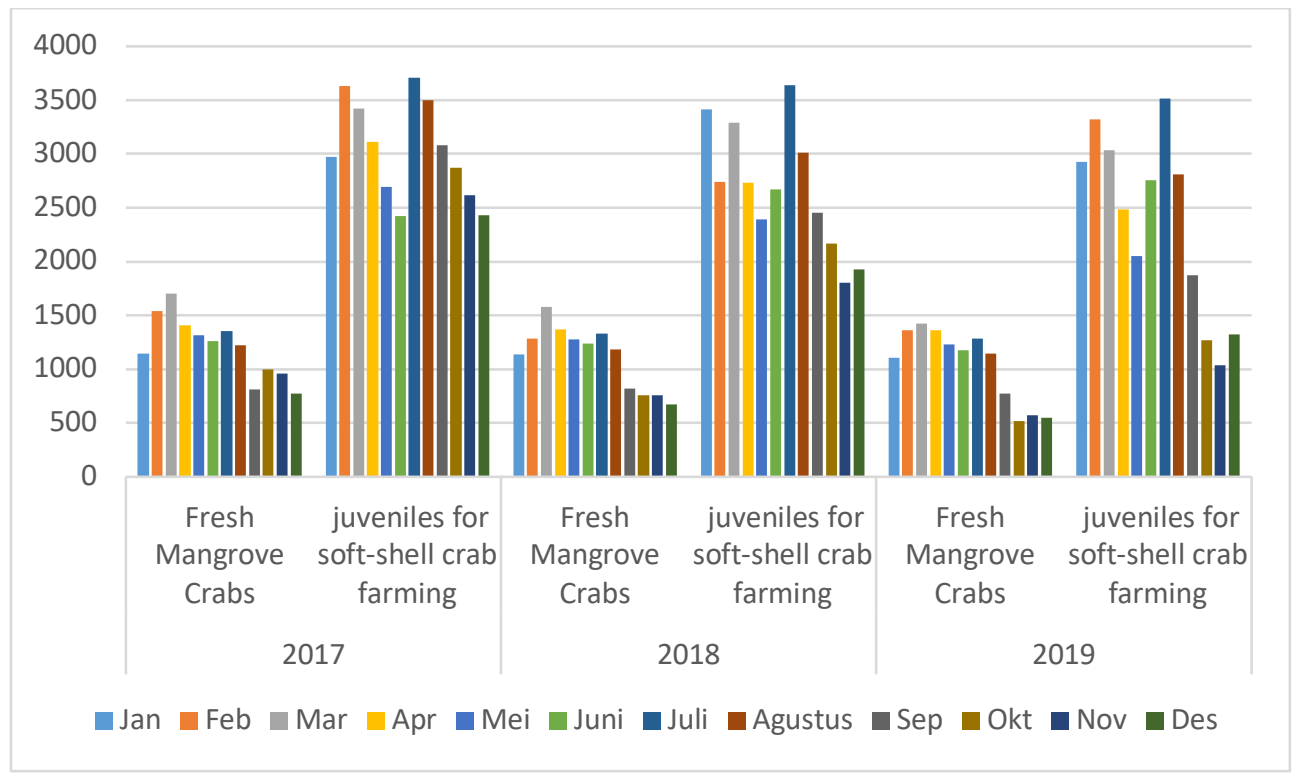

Fig. 1. Diagrams of mud crab catches

In Figure 1 shows that anthropogenic pressure on mud crabs in the Mojo mangrove ecosystem increases during the west monsoon season (rainy season), it is caused during the rainy season the mud crabs make a reproductive phase $[18,19,20]$. Differences in peak reproductive seasons may be related to the suitability of the environmental conditions of the waters in supporting the reproduction process. Thus there is a possibility of a change in the peak of the reproductive season from year to year due to global climate change [21, 22].

Furthermore, during the west monsoon season the number of fishermen who catch mud crabs in the mangrove and fishpond ecosystems increases. During the west monsoon season, many fishermen do not go to sea, in the January-May period. The west monsoon season, known as the rainy season, is characterized by high rainfall accompanied by winds and storms. Fishermen adopt an adaptation strategy by finding substitute commodities as a source of livelihood by switching to crabbing in the mangrove ecosystem on the Mojo Coastal Area.

During the west monsoon season, the catch per trip ranges from 20-50 crabs and is large in size, but during the east monsoon season it only ranges between 5-10 crabs and is small in size. Information obtained from fishermen stated that female sex was caught more than male sex, with a minimum ratio of 1:20 (male:female). Observation results indicate that the majority of mud crabs caught are not in accordance with regulations (size $<12 \mathrm{~cm}$ ) with $70 \%$ of the total catch of mud crabs for soft shell crab farming needs.

Mojo Village, Ulujami Subdistrict, Pemalang Regency, is a center for the cultivation of soft-shell crab (Scylla spp.). In this village there are 6 ponds with an average area of 0.5 ha / ponds and the production of soft-shell crabs (Scylla spp.) an average of $2000 \mathrm{~kg} /$ month / ponds [23]. The Mojo Village Mangrove Area covers an area of 72 ha with an area of 327 ha of aquaculture ponds used for milkfish, vanamei shrimp and soft-shell mud crabs [24], so that the soft-shell crab farmers rely solely on seedlings from capturing mud crab in the mangrove forest. 


\subsubsection{Environmentally friendly analysis on mud crab (Scylla spp.) fishery in Mojo} Mangrove Ecosystem

Based on the Regulation of the Minister of Maritime Affairs and Fisheries of the Republic of Indonesia Number 12 of Year 2020 concerning Management of Lobster (Panulirus Spp.), Mud Crab (Scylla spp.), and Rajungan (Portunus Spp.) in the Territory of the Republic of Indonesia, Article 7 states that mud crab fishing must be carried out using fishing gear that is static or passive. The fishing gear analyzed in this study were crab traps, trammel net, and crabbing with a line and scoop net. The three fishing gears are fishing tools that are operated statically and passively in accordance with regulations.

Environmentally friendly analysis using Code of Conduct for Responsible Fisheries (CCRF) criteria which includes, has a high selectivity, does not damage the habitat, no endangering fishermen, producing good quality fish, products not endangering consumers, low by-catch, minimum impact on biodiversity, not capturing protected species, and socially accepted. Rating scores are taken from interviews with each respondent per type of fishing gear. Then determined the score on each fishing gear presented in the Table 3.

Table 3. The environmental friendly score of mangrove crab fishing gear in Mojo mangrove ecosystem

\begin{tabular}{|r|l|c|c|c|}
\hline \multirow{2}{*}{} & \multicolumn{1}{|c|}{ Criteria } & \multicolumn{3}{c|}{ Fishing Gear } \\
\cline { 3 - 5 } No. & \multicolumn{1}{|c|}{$\begin{array}{c}\text { Crab } \\
\text { Traps }\end{array}$} & $\begin{array}{c}\text { Trammel } \\
\text { Net }\end{array}$ & $\begin{array}{c}\text { Crabbing with a } \\
\text { Line and Scoop } \\
\text { Net }\end{array}$ \\
\hline 1 & Fishing gear selectivity & 3.00 & 1.27 & 2.00 \\
\hline 2 & Impact on habitat & 4.00 & 3.54 & 4.00 \\
\hline 3 & Quality of catch & 3.73 & 3.12 & 4.00 \\
\hline 4 & $\begin{array}{l}\text { Safety of the fishing gear } \\
\text { operation }\end{array}$ & 3.82 & 2.77 & 3.38 \\
\hline 5 & Product safety for consumers & 4.00 & 3.92 & 4.00 \\
\hline 6 & Non-target species & 3.09 & 2.46 & 4.00 \\
\hline 7 & Impact on biodiversity & 3.45 & 3.19 & 3.73 \\
\hline 8 & Impact on protected species & 3.86 & 3.27 & 3.47 \\
\hline 9 & Social acceptance & 3.42 & 3.27 & 3.82 \\
\hline & Total & 32.37 & 26.81 & 32.40 \\
\hline
\end{tabular}

Crabbing with a line and scoop net fishing gear have the highest value compared to other fishing gear with a value of 32.40 followed by crab traps with a value of 32.37 . Trammel net has the lowest value (total score 26.81) because this fishing gear caught more than three species of vastly different sizes and some of the catches are damaged or physically defective, so the quality is not good. Based on the research that has been carried out, the catches of each fishing gear traps, trammel net, crabbing with a line and scoop net vary with the size of 8- 14 $\mathrm{cm}, 5-10 \mathrm{~cm}, 5-14 \mathrm{~cm}$. The size of these catches, mostly do not comply with Regulation of the Minister of Maritime Affairs and Fisheries of the Republic of Indonesia Number 12 Year 2020 , because in accordance with established regulations that mud crab fishing can be done 
if the size of carapace on captured mud crab measuring $>12 \mathrm{~cm}$, while the catches of mud crabs is mostly for soft shell crab farming needs with size of carapace $<12 \mathrm{~cm}$. Based on the score of the fishing gear environmentally friendly assessment shown in table 3 , it is known that the three groups of fishing gear are environmentally friendly fishing gears, it's just that the behavior of mud crab fishermen who ignore the regulations needs attention to realize responsible and sustainable use of mud crab resources.

The condition of mud crabs caught by trammel net fishing gear is entangled or dangled by nets $[25,26,27]$. During the trapped process, it is suspected that mud crabs will try to escape and this can cause stressed and injured mud crabs with incomplete limbs because there are parts of their limbs that are cut off or mud crabs are no longer intact. This causes the crab trap to be preferred by fishermen compared to trammel net. While the condition of crabs caught on the crab trap and crabbing with line and scoop net are alive and all members are complete, so the selling price is relatively high. The three types of mud crabs fishing gear that are operated are fishing gear that has never caught protected fish species.

Social acceptance score of crabbing with a line and scoop net fishing gear is the higest because this fishing gear investment is cheap, profitable, very easy to operate, easy to maintain, easy to store and does not require a boat for mud crab fishing operations. Based on interviews with fishermen, in general all fishing gear operated to catch mud crabs is profitable, although the benefits are not greater than in previous years, because there are no regulations at the local level governing the sustainable use of mud crab resources. Socially, these fishing gear can absorb labor and are the ultimate source of livelihood in times of bad weather or no other work can be done.

Pemalang Regency has 786 fishing boats with a capacity of $5 \pm 10$ GT, but from 786 the number of fishing boats, only about 200 fishing boats that have been have a permit, which means there are still about $74.6 \%$ of fishing boats in Pemalang Regency do not have a license [28]. Some of the causes of this problem are: (1) the low level of awareness of the fishermen to make a fisheries business permit, (2) the existence of Community Surveillance Group (POKMASWAS) as implementing supervisory at the field level has not been running optimally, (3) there is still a lack of volume in conducting raids or controlling permits due to limited funds and the absence of sanctions imposed.

The high intensity of mud crab fishing operations and the increasing number of fishing gear, especially during the west monsoon season, is a serious threat and pressure on mud crab resources, so the challenges in implementing Regulation of the Minister of Maritime Affairs and Fisheries of the Republic of Indonesia no.12 Year 2020 are, among others, by recording fishermen who carry out the activities of catching mud crabs and complete a permit to catch and record the catch of mud crabs so that they can become an accurate database in formulating management efforts.

\section{Conclusion}

Mud crabs fishing is carried out throughout the year, the harvest season occurs when it enters the rainy season. The majority of mud crabs caught are not in accordance with regulations (size $<12 \mathrm{~cm}$ ) with $70 \%$ of the total catch of mud crabs for soft-shell crab farming needs. The fishing gears used to catch mud crabs in the Mangrove Ecosystem Waters of Mojo Village, Ulujami District, Pemalang Regency are environmentally friendly fishing gear. But there are criteria that do not meet environmentally friendly scores on all fishing gear namely catching mud crabs with size that is prohibited and there are still many non-target species caught with trammel net. 


\section{References}

[1] J.W. Creswell. Research Design Qualitative, Quantitative and Mixed Methods Approaches (4th ed.). (2014).

[2] J.F. Molina-Azorin \& M.D. López-Gamero. Business Strategy and the Environment, 25, 134-148. (2016).

[3] D.M. Mertens, P. Bazeley, L. Bowleg, N. Fielding, J. Maxwell, J.F. Molina-Azorin, K. Niglas. (2016).

[4] J.F. Molina-Azorin. Organizational Research Methods, 15, 33-56. (2012).

[5] Food and Agriculture Organization. Code of Conduct for Responsible Fisheries. ISBN 92-5-103834-5. 41 hlm. (1995).

[6] E. Coning, E. Witbooi. Marine Policy. 60 (October): 208-215. (2015).

[7] A.P. Gumilang \& E. Susilawati. ICMS 2019 IOP Conf. Series: Earth and Environmental Science 429 (2020) 012049 IOP Publishing. (2020).

[8] A. Hanafi, H. Riniwati, A. Afandhi. J-PAL, Vol. 10, No. 2, ISSN: 2087-3522. (2019).

[9] Marine and Fishery Office of Pemalang Regency. Fishing Capture Profil of Pemalang Regency. (2019).

[10] D.O. Mirera. African Journal of Marine Science, 39:3, 315-325. (2017).

[11] B. Photo \& B. Joyanta. Mud crab's (Scylla serrata) Reproduction and Breeding Technique Course. 10.13140/RG.2.2.29718.70723. (2016).

[12] Department of Fisheries. Fisheries Fact Sheet Mud crab. Fisheries Fact Sheet (28): www.fish.wa.gov.au. Australia. (2013).

[13] H. Alberts-Hubatsch, S.Y. Lee, J. Meynecke. Hydrobiologia 763, 5-21 (2016).

[14] K.A. Huq, S.B. Rahaman and A.F.M. Hasanuzzaman. Environmental Management and Governance (pp. 175-198). Springer International Publishing. (2015).

[15] R. Irnawati, A. Susanto \& S.L.A. Maesaroh. Jurnal Perikanan dan Kelautan Vol. 4 No. 4 : 277-282. (2014).

[16] Sunarto, Sulistiono \& I. Setyobudiandi. Marine Fisheries ISSN 2087-4235, 6(1): 59-68. (2015).

[17] Sunarto, Sulistiono \& I. Setyobudiandi. Marine Fisheries. 6 :59-68. (2016).

[18] E. Yudiati, A.T. Fauziah, Irwani, A. Setyawan \& Insafitri. Jurnal Kelautan Tropis. 23(1):136-144. (2020).

[19] C. Viswanathan, M. Pravinkumar, T. V. Suresh, V. Elumalai \& S. M. Raffi. Indian J. Fish., 66 (1): 26-33. (2019).

[20] M.Y. Ali, Md. B. Hossain, S. Sana, M.A. Rouf, S. Yasmin, M.G. Sarower. 6 (6): e04318, ISSN 2405-8440. (2020).

[21] H. Alberts-Hubatsch. Dissertation. Faculty of Biology/Chemistry University Bremen Germany. (2015).

[22] M. Jan-Olaf, M. Grubert \& J. Gillson. Marine and Freshwater Research, 63:84-94. (2012).

[23] Mojo Village Government. Mojo Village Profile. (2015).

[24] A. Purnamawati, S. Saputra \& D. Wijayanto. Management of Aquatic Resources Journal (MAQUARES). 4 (3):204-213. (2015).

[25] E. Gillman. Marine Policy. 60(October) : 225-239. (2015). 
[26] T. Cashiona. D. Al-Abdulrazzak. D. Belhabib. B. Derrick. E. Divovich. D.K. Moutopoulos. S.L. Noël. M.L.D. Palomares. L.C.L.Teh. D. Zeller. D. Pauly. 206 (October) : 57-64. (2018).

[27] R. Cosgrove. M. Gosch. D. Reid. M. Sheridan. N. Chopin. M. Jessopp. M. Cronin. 183 :192-199. (2016).

[28] M. Naibaho \& T. Yuwono. Journal of Politic and Government Studies, 6 (2):391-400. (2017). 